\title{
サイクロコンバータと電源系統間の 高調波共振現象の解析
}

\author{
正員池田 春 男 (鉄道総研) \\ 正員川口育夫 (鉄道総研) \\ 正員加 賀 重 夫 (鉄道総研)
}

\section{Harmonic Resonance Phenomenon between Cycloconverter and Utility Power System}

Haruo Ikeda, Member, Ikuo Kawaguchi, Member, Shigeo Kaga, Member(Railway Technical Research Institute)

In the circulating current type cycloconverter system, a harmonic resonance is induced by the inductance of the utility power system, shunt capacitors, and the cycloconverter. This harmonic resonance has an influence on the operation of the cycloconverter. This paper describes the analysis of this harmonic resonance phenomenon. Namely, the conversion process for the harmonics in the cycloconverter is analyzed, and the relation between the harmonic resonance phenomenon and the respective capacities of the utility power system and the shunt capacitors is examined based on results of the analyses. Moreover the analyses are confirmed by the field test.

キーワード：高調波共振現象, サイクロコンバータ, 電力変換

\section{1.はじめに}

サイクロコンバータは回路構成が単純であり，かつ 洒格も低廉であることから，大容量器では広く使用さ れている。特に，その入力側に進相コンデンサを挿入 した循環電流式サイクロコンバー夕は，従来のサイク ロコンバータのもつ入力無効電力などの問題を克服す ることが可能であり，浮上式鉄道用のVVVF 電源と して, $16 \mathrm{MVA}$ もの大容量器が使用されている(1)(2)。

しかしながう，このような電力変換方式ては，入力 側に挿入された進相コンテンサと電源系統のインダク タンスとの間で，高調波共振現象が発生することがあ る。そして，このために入力電圧波形がひずむと，サ イクロコンパータの入力電流波形も，この次数の高調 波成分を多く含むようになり，更に共振現象を搪大し て，場合によってはサイクロコンバータトランスの直 流偏磁などにまで至るようになってくる。

従来, 検討されてきた, サイリス夕回路と電源系統
との高調波共振（不安定）現象は，電圧波形のひずみ によってサイリスタ点弧角が動摇することに起因する ものてあり ${ }^{(3)}$ ，これを防止するためにPLL制御回路 を用いることがある。しかしながら，大容量器ては， このような PLL 制御回路でも十分対処できず，出力 側電流に高調波成分が発生し，この高調波成分が入力 側に変換されることによって共振現象が発生する場合 がある。

本論文は，このような電源系統〜進相コンデンサ 〜サイクロコンバータ間の高調波共振現象を解析した ものである。はじめに, サイクロコンバータの高調波 に対する変換動作について解析を行う。すなわち，入 力電圧高調波がどのようにサイクロコンバー夕の出力 側（二次側）に変換されるかを明らかにし，この変換 された高調波電圧による二次側電流への影稫について 娭討を加え, 更に,この二次側電流がどのように入力 側に変換されるかを明らかにする。

次に,このサイクロコンバータの解析結果をもと 
に, 電源インダクタンス值ならびに進相コンデンサ容 量と, 高調波共振現象との関係について検討を加え る。最後に，浮上式鉄道宮崎実験線の大容量サイクロ コンバータによって, 以上の検討結果を確認してい る。

\section{2. 循㻒電流式サイクロコンバータの棈成と 原理}

図1に示すように，循環電流式サイクロコンバー夕 では, 正群コンバータ PC と負群コンバータ NCを, リアクトルを介して逆並列に接続している。出力電流 $i_{L}$ の正方向成分は正群コンバータを, 逆方向成分は 負群コンバータをそれぞれ流れる。また, 偱環電流 $i c$ は, 正群〜負群コンパータ間を流れる。icは正群

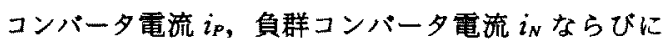
出力電流 $i_{L}$ より演算され， $i_{L}$ と $i_{C}$ がそれそれその目 標值 $i_{L}{ }^{*}, i_{C}{ }^{*} に 一$ 致するように, 位相制御電圧 $e_{P}$, 䄈を制御している。

サイクロコンバータの入力側には, 進相コンデンサ CAPが接続される。そして，進相コンデンサの発生 する進相無効電力とサイクロコンバータの発生する遅 相無効電力とが, 常に打消し合うように, 循環電流の 大きさを調整制御している。

\section{3. サイクロコンパータの動作解析}

〈3・1〉 二次側电圧波形解析にあたっては, 単 相出力 3 パルスサイクロコンバータを考えることにす る。ここで, 入力変圧器の巻数比を 1 とし, そのイン ピーダンスを0（電流重なりを無視する）とすれば, 正群コンバータが位相制御角 $\alpha$ で運転されたとき, その二次側電在 $v_{p}$ は次のように表される(4)。

$$
\begin{aligned}
v_{p}= & v_{R} F_{R}\left(\theta_{i}-\alpha\right)+v_{S} F_{S}\left(\theta_{i}-\alpha\right) \\
& +v_{T} F_{T}\left(\theta_{i}-\alpha\right) \quad \cdots \ldots \ldots \ldots \ldots
\end{aligned}
$$

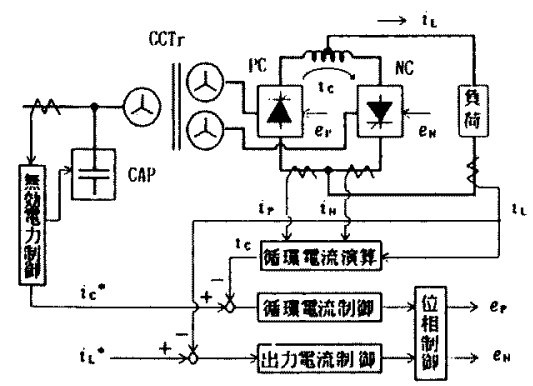

図 1 循環電流式サイクロコンバー夕の構成

Fig. 1. The configuration of the circulating current type cycloconverter.
$v_{R}, v_{S}, v_{T}: R$ 相，S相扝よび $T$ 相電圧， $F_{R}\left(\theta_{i}-\alpha\right), F_{S}\left(\theta_{i}-\alpha\right), F_{T}\left(\theta_{i}-\alpha\right):$ 正群 コ ンバー夕内の $R$ 相, $S$ 相および $T$ 相サイリ

スタのスイッチング関数

ここで, 入力電压には $k$ 次高調波成分が含まれて いるものとし， $v_{R} ， v_{S}, v_{T}$ を次のように表す。

$$
\left.\begin{array}{l}
v_{R}=V_{1} \sin \theta_{i}+V_{k} \sin \left(k \theta_{i}+\delta\right) \\
v_{S}=V_{1} \sin \left(\theta_{i}-\frac{2 \pi}{3}\right)+V_{k} \sin \left(k \theta_{i}+\delta \mp \frac{2 \pi}{3}\right) \\
v_{T}=V_{1} \sin \left(\theta_{i}+\frac{2 \pi}{3}\right)+V_{k} \sin \left(k \theta_{i}+\delta \pm \frac{2 \pi}{3}\right)
\end{array}\right\}
$$

$V_{1}$ : 基本波成分の波高值， $\theta_{i}:$ 入力位相角,

$k$ : 高調波次数, $V_{k}: k$ 次高調波成分の波高

値, $\delta$ : 高調波の初期位相

ただし，上式中の記号干，士は $k$ 次高調波電圧が正 相のときは上側，逆相の時は下側の符号をとるものと する。

上式を(1)式に代入して整理すれば，次のようにな る。

$$
\begin{aligned}
v_{P}= & V_{1}\left\{\sin \theta_{i} F_{R}\left(\theta_{i}-\alpha\right)\right. \\
& +\sin \left(\theta_{i}-\frac{2 \pi}{3}\right) F_{s}\left(\theta_{i}-\alpha\right) \\
& \left.+\sin \left(\theta_{i}+\frac{2 \pi}{3}\right) F_{T}\left(\theta_{i}-\alpha\right)\right\} \\
& +V_{k}\left\{\sin \left(k \theta_{i}+\delta\right) F_{R}\left(\theta_{i}-\alpha\right)\right. \\
& +\sin \left(k \theta_{i}+\delta \mp \frac{2 \pi}{3}\right) F_{s}\left(\theta_{i}-\alpha\right) \\
& \left.+\sin \left(k \theta_{i}+\delta \pm \frac{2 \pi}{3}\right) F_{T}\left(\theta_{i}-\alpha\right)\right\}
\end{aligned}
$$

上式中の第 1 項は，入力電圧中の基本波成分 $V_{1}$ の 二次側変換波形である。また，第 2 項は高調波成分 Vk変換波形である。ここでは, 高調波成分の変換 波形について解析することを目的としているので, 以 後、第 2 項のみを論ずることにする。

一般に，サイリスタのスイッチング関数は次のよう に表すことができる(4)。

$$
F\left(\theta_{i}\right)=\frac{1}{3}+\sum_{n=1}^{\infty}\left(a_{n} \cos n \theta_{i}+b_{n} \sin n \theta_{i}\right)
$$

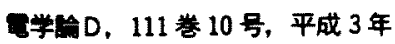




$$
\left.\begin{array}{l}
a_{n}=\frac{2}{n \pi} \cos \frac{n \pi}{2} \sin \frac{n \pi}{3} \\
b_{n}=\frac{2}{n \pi} \sin \frac{n \pi}{2} \sin \frac{n \pi}{3}
\end{array}\right\}
$$

各サイリスタのスイッチング関数について，それぞ れ(4)式加求め, これを(3)式の第 2 項に代入して 整理すれば, 正群コンバータの二次側電圧中の $V_{k} に$ よる成分 $v_{P K}$ が，次の上うに求められる。

$$
\begin{aligned}
v_{P K}= & \pm \frac{3 \sqrt{3} V_{k}}{2 \pi} \cos \left\{(k \mp 1) \theta_{i}+\delta \pm \alpha\right\} \\
& +\frac{3 V_{k}}{2} \sum_{m=1}^{\infty}\left[a _ { 3 m - 1 } \operatorname { s i n } \left\{(k \pm 3 m \mp 1) \theta_{i}\right.\right. \\
& +\delta \mp(3 m-1) \alpha\} \\
& \mp b_{3 m-1} \cos \left\{(k \pm 3 m \mp 1) \theta_{i}\right. \\
& +\delta \mp(3 m-1) \alpha\} \\
& +a_{3 m+1} \sin \left\{(k \mp 3 m \mp 1) \theta_{i}\right. \\
& +\delta \pm(3 m+1) \alpha\} \\
& \pm b_{3 m+1} \cos \left\{(k \mp 3 m \mp 1) \theta_{i}\right. \\
& +\delta \pm(3 m+1) \alpha\}] \cdots \cdots \cdots \cdots \cdots \cdots
\end{aligned}
$$

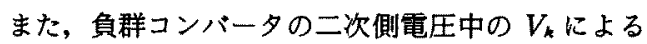
成分 $v_{N K}$ は，(6)式において $(\alpha=-\alpha)$ と置き, 電圧 極性が逆であることに注意すれば，次式のように表さ れる。

$$
\begin{aligned}
v_{N K}= & \pm \frac{3 \sqrt{3} V_{k}}{2 \pi} \cos \left\{(k \mp 1) \theta_{i}+\delta \mp \alpha\right\} \\
& +\frac{3 V_{k}}{2} \sum_{m=1}^{\infty}\left[a _ { 3 m - 1 } \operatorname { s i n } \left\{(k \pm 3 m \mp 1) \theta_{i}\right.\right. \\
& +\delta \pm(3 m-1) \alpha\} \\
& \mp b_{3 m-1} \cos \left\{(k \pm 3 m \mp 1) \theta_{i}\right. \\
& +\delta \pm(3 m-1) \alpha\} \\
& +a_{3 m+1} \sin \left\{(k \mp 3 m \mp 1) \theta_{i}\right. \\
& +\delta \mp(3 m+1) \alpha\} \\
& \pm b_{3 m+1} \cos \left\{(k \mp 3 m \mp 1) \theta_{i}\right. \\
& +\delta \mp(3 m+1) \alpha\}] \cdots \cdots \cdots \cdots \cdots \cdots(
\end{aligned}
$$

(6)式および(7)式の第 1 項はパルス数に依存しな い成分であり，第 2 項はパルス数に依存する成分であ る。本論文では, 高調波共振次数に対して, サイクロ コンバータのパルス数は十分大きいものとして, 以 後, 第 1 項についてのみ論ずることにする。

サイクロコンバータの出力電圧 $v_{L}$ は $v_{P}$ と $v_{N}$ の平 均, 循環電流系の電圧 $v_{C}$ は $v_{P}$ と $v_{N}$ の差でそれぞれ 表される。それゆえ，k次高調波成分についても同様 に，そのパルス数に依存しない成分 $v_{L K}{ }^{\prime}, v_{C K}{ }^{\prime}$ は, (6)式および(7)式から, それぞれ次のように求めら れる。

$$
\begin{gathered}
v_{L K^{\prime}}= \pm \frac{3 \sqrt{3} V_{k}}{2 \pi} \cos \left\{(k \mp 1) \theta_{i}+\delta\right\} \cos \alpha \\
\cdots \ldots \ldots \ldots \ldots \ldots \ldots \ldots \ldots \ldots \ldots \ldots \ldots \ldots \ldots \ldots \ldots \ldots \ldots \ldots \\
v_{C K^{\prime}}=-\frac{3 \sqrt{3} V_{k}}{\pi} \sin \left\{(k \mp 1) \theta_{i}+\delta\right\} \sin \alpha
\end{gathered}
$$

一方, 出力電圧が交流波形となるためには，位相制 御角 $\alpha$ は次式のように与えられなければならない(い)。

$$
\alpha=\pi / 2-\sin ^{-1}\left(r \sin \theta_{0}\right)
$$

たたし,$r$ : 出力電圧比, $\theta_{0}$ : 出力位相角

上式を(8)，(9)式に代入して整理し， $P$ パルス サイクロコンバータについて拡張すれば,一般に, $k$ 次入力電圧高調波は次のように二次側に変換される。

$$
\begin{aligned}
v_{L K P^{\prime}}= & \pm \frac{P \sqrt{3} V_{k} r}{2 \pi} \\
& \times\left[\sin \left\{(k \mp 1) \theta_{i}+\delta+\theta_{0}\right\}\right. \\
& \left.-\sin \left\{(k \mp 1) \theta_{i}+\delta-\theta_{0}\right\}\right] \cdots \cdots \cdot(11) \\
v_{C K P^{\prime}}= & -\frac{P \sqrt{3} V_{k}}{\pi} \\
& \times\left[\sum _ { i = 0 } ^ { \infty } A _ { ( 0 ) 2 1 } \left[\sin \left\{(k \mp 1) \theta_{i}+\delta+2 l \theta_{0}\right\}\right.\right. \\
& \left.\left.+\sin \left\{(k \mp 1) \theta_{i}+\delta-2 l \theta_{0}\right)\right]\right]
\end{aligned}
$$

$v_{L K P^{\prime}}: P$ パルスサイクロコンバータの, $k$ 次入力電圧高調波が変換された出力電圧スぺ クトラムのなかで，パルス数に依存しない成 分, $v_{C K p^{\prime}}$ ：循環電流系に対する同様の成分 ただし，

$$
\left.\begin{array}{rl}
A_{(0) 0}= & \frac{1}{2 \pi} \int_{0}^{2 \pi} \cos \left\{\sin ^{-1}\left(r \sin \theta_{0}\right)\right\} d \theta_{0} \\
\mathrm{~A}_{(0) 2 l}= & \frac{1}{\pi} \int_{0}^{2 \pi} \cos \left\{\sin ^{-1}\left(r \sin \theta_{0}\right)\right. \\
& \left.\times \cos 2 l \theta_{0}\right\} d \theta_{0}
\end{array}\right\}
$$

(11)式で表される, 出力電圧高調波 $v_{L K P^{\prime}}$ の振幅と 次数について示したものが, 図2である。ここでは, 簡単のために $P=1, V_{k}=1$ としている。出力電圧高 調波の振幅はサイクロコンバータの出力電圧比 $r$ と 比例関係にあるため, $r$ が大きいほど振幅も大きく， $r=1.0$ では約 0.28 となる。一方, その高調波次数 は, 入力電圧高調波が正相の場合は $(k-1)$ 次, 逆相 の場合は $(k+1)$ 次となる。また, 入出力周波数比が 大きくなるに従い, 次数が変化していく。

同棣に，(12)式で表される，循瑔電流ルーブに対す る高調波電圧 $v_{C K P}{ }^{\prime}$ の振幅と次数について示したもの 


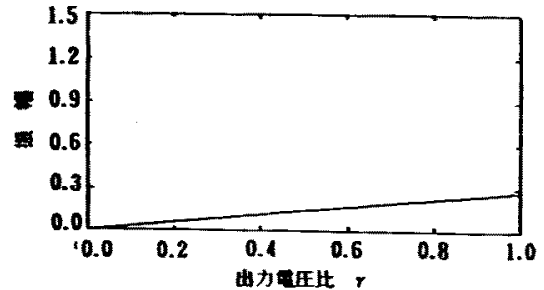

(a)

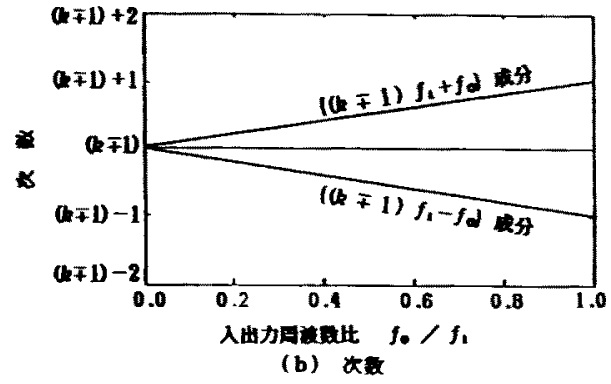

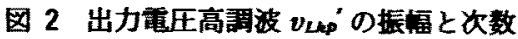

$$
\left(P=1, V_{k}=1\right)
$$

Fig. 2. The amplitude and order of the harmonic component $v_{L \varphi p}$ in the output voltage $\left(P=1, V_{k}=1\right)$.
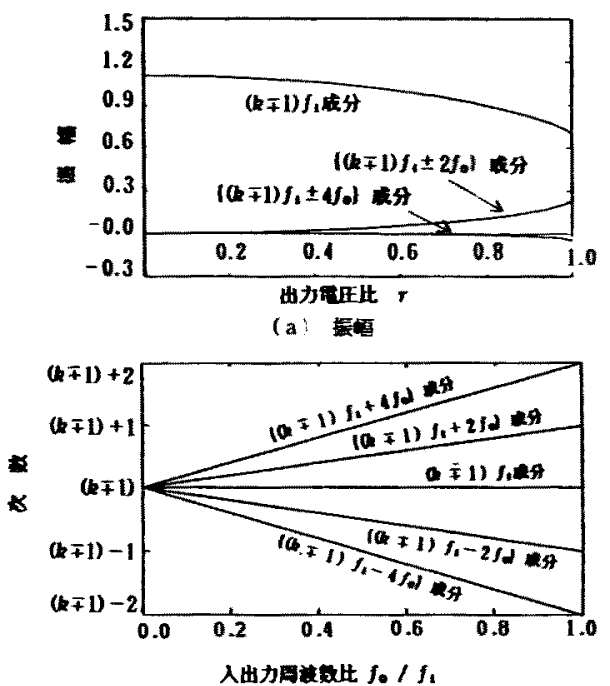

(b) 大

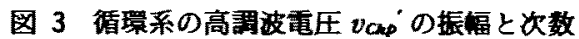
$\left(P=1, \quad V_{k}=1\right)$

Fig. 3. The amplitude and order of the harmonic voltage $v_{c w}{ }^{\prime}$ in the circulating current circuit $\left(P=1, V_{k}=1\right)$.

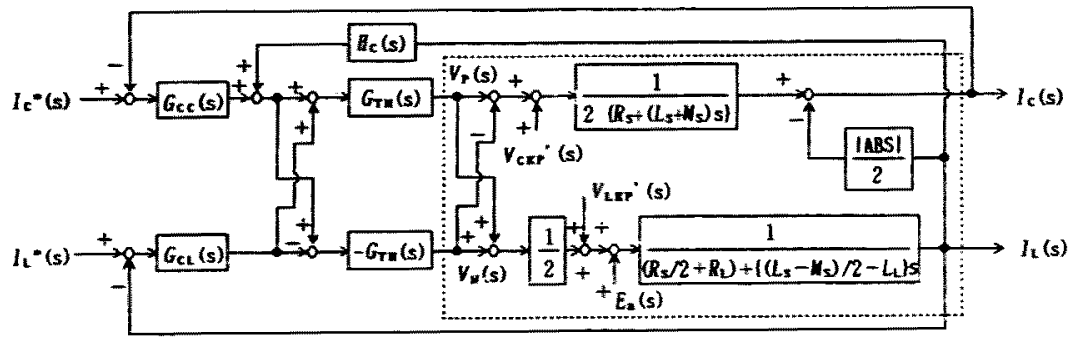

図 4 電流制御系の棈成図

Fig. 4. A block diagram of the current control circuit.

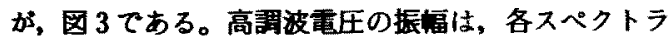
ムのなかで, $l=0$ の成分 [(k干1) $f_{i}$ 成分]が他の成分 に比へて相当大きい。このスべクラム成分は出力周 波数の影製を受けないのて，常に，(k-1)次らるい は $(k+1)$ 次の次数をもつことになる。

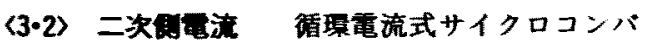

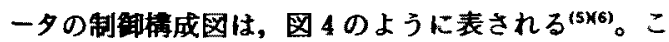
こて，図中の記号は表1に示すとおりである。この構

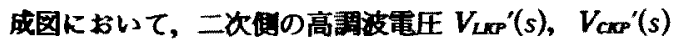
は，図中の簓所に外吉として加わることになる。この

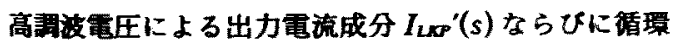

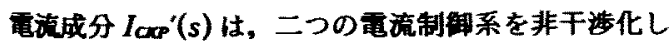
た状志ては，次式のように表される。

$$
\left[\begin{array}{l}
I_{L K P}(s) \\
I_{C K P^{\prime}}(s)
\end{array}\right]=\left[\begin{array}{cc}
G_{L K}(s) & 0 \\
0 & G_{C K}(s)
\end{array}\right]\left[\begin{array}{l}
V_{L K P}^{\prime}(s) \\
V_{C K P^{\prime}}(s)
\end{array}\right]
$$
$\geq \Xi$

$$
\left.\begin{array}{l}
G_{L K}(s)=\frac{G_{1}(s)}{1+G_{1}(s) G_{C L}(s) G_{r H}(s)} \\
G_{C K}(s)=\frac{G_{Z}(s)}{1+2 G_{z}(s) G_{C \alpha}(s) G_{r H}(s)}
\end{array}\right\}
$$
ただし。

$$
\left.\begin{array}{l}
G_{1}(s)=\frac{1}{\left(R_{S} / 2+R_{L}\right)+\left\{\left(L_{s}-M_{s}\right) / 2+L_{L}\right\}_{s}} \\
G_{2}(s)=\frac{1}{2\left(R_{s}+\left(L_{s}+M_{s}\right) s\right\}}
\end{array}\right\}
$$


表 1 電流制御系の記号

Table 1. The symbols of the current control circuit.

\begin{tabular}{|c|c|}
\hline 能 亭 & 肉 \\
\hline$G_{\mathrm{tat}}(s)$ & 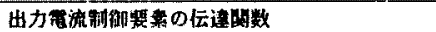 \\
\hline$G_{\mathrm{sc}}(s)$ & 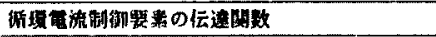 \\
\hline$G_{\mathrm{TK}}(s)$ & コンパータの伝違閶数 \\
\hline$H_{c}(s)$ & 非间化のためのフィードバック枟遑的数 \\
\hline$R_{3}$ & 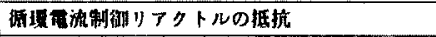 \\
\hline$L_{s}$ & “ の自己インタクタンス \\
\hline $\mathrm{Ms}_{\mathrm{s}}$ & の相互インタクタンス \\
\hline$R_{L}$ & 具俌抵抗 \\
\hline$L_{L}$ & 頜捕インダクタンス \\
\hline E. $(s)$ & 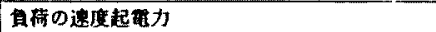 \\
\hline
\end{tabular}

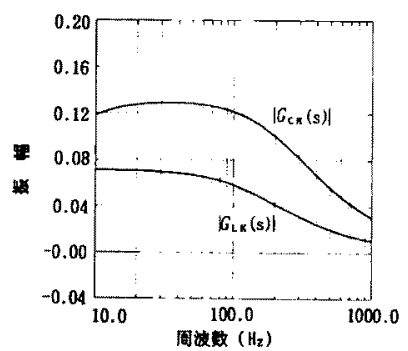

(a) 振幅

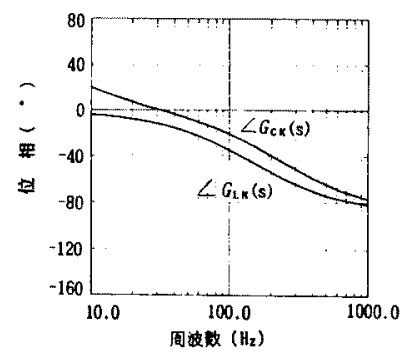

(b) 位相

図 5 高調波電圧に対する伝達関数

Fig. 5. The transfer function for the harmonics voltage.

ここで，s:ラプラス演算子

図 5 は二つの伝達関数 $G_{L K}(s), G_{C K}(s)$ の周波数特 性を表したものである。ここで，各定数は，表 2 に示 す宮崎実験線のサイクロコンバータの值を用いてい る。図において，二つの伝達関数のなかでは $G_{C K}(s)$

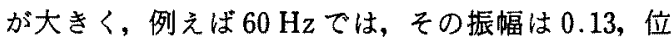
相は $10^{\circ}$ 遅れとなっている。

これまでの検討結果より，二次側に変換された高調 波電圧は, 循瑷電流系のものが出力電流系のものより
表 2 サイクロコンバー夕の制御定数 Table 2. The control constants of the cycloconverter.

\begin{tabular}{|c|c|}
\hline 跑 号 & 定 \\
\hline$G_{\mathrm{EL}}(s)$ & 2.0 \\
\hline$G_{s c}(s)$ & $3.5 \times(1+0.0262 s) /(1+0.1991 S)$ \\
\hline$G_{T H}(s)$ & $1323.5 / 200 \cdot \mathrm{e}^{-1 .}$ \\
\hline$\tau$ & $0.000347(s)$ \\
\hline$R_{s}$ & $0.80064(\Omega)$ \\
\hline$L_{3}$ & $0.001+0.000556$ (11) \\
\hline$M_{s}$ & $0.001 \quad$ (11) \\
\hline$R_{L}$ & $0.4522 \quad(\Omega)$ \\
\hline$L_{\mathrm{L}}$ & $0.01512 \quad$ (II) \\
\hline
\end{tabular}

も相当大きい。また，上述のように，これら二つの電 流系に単位高調波電圧を加えた場合, 循䍗電流中の高 調波成分のほうが大きい。それゅえ，高調波共振現象 を検討するにあたっては，循環電流ループのみを考虑 すればよいことがわかる。以後, 本論文では, この循 環電流系の $(k \mp 1) f_{i}$ 成分のみを検討することにする。 〈3・3〉入力電流循環電流中の優勢高調波であ

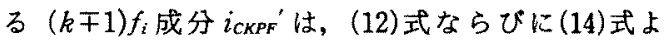
り，次のように表される。

$$
\begin{aligned}
i_{C K P F}= & -\frac{P 2 \sqrt{3} V_{K} A_{(0) 0} G_{C K}}{\pi} . \\
& \times \sin \left\{(k \mp 1) \theta_{i}+\delta+\phi_{C K}\right\}
\end{aligned}
$$

ただし， $G_{C K}:(k \mp 1) f_{i} に お け る G_{C K}(s)$ の

振幅, $\phi_{C K}:(k \mp 1) f_{i}$ に扮ける $G_{C K}(s)$ の位相 単相 $P$ パルスサイクロコンバータにおいては, 上 式の循環電流による， $R$ 相入力電流中のパルス数に 依存しない成分惊，次式のように表される(7)。

$$
\begin{aligned}
i_{R K P^{\prime}}= & -\frac{2 \sqrt{3} i_{C K P F^{\prime}}}{\pi} \sum_{i=0}^{\infty} A_{(0) 2 l} \cos \theta_{i} \cos 2 l \theta_{0} \\
= & \frac{P^{2} 2 V_{K}\left(A_{(0) 0}\right)^{2} G_{C K}}{\pi^{2}} \\
& \times\left[\sin \left(\{(k \mp 1)+1\} \theta_{i}+\delta+\phi_{C K}\right]\right. \\
& \left.+\sin \left[\{(k \mp 1)-1\} \theta_{i}+\delta+\phi_{C K}\right]\right]
\end{aligned}
$$

同様に, $S$ 相ならびに $T$ 相入力電流は, 次式のよ うに表される。

$$
\begin{aligned}
i_{S K P^{\prime}}= & \frac{P^{2} 2 V_{K}\left(A_{(0) 0}\right)^{2} G_{C K}}{\pi^{2}} \\
& \times\left[\sin \left[\{(k \mp 1)+1\} \theta_{i}-\frac{2 \pi}{3}+\delta+\phi_{C K}\right]\right. \\
& \left.+\sin \left[\{(k \mp 1)-1\} \theta_{i}+\frac{2 \pi}{3}+\delta+\phi_{C K}\right]\right]
\end{aligned}
$$




$$
\begin{aligned}
i_{T K P^{\prime}}= & \frac{P^{2} 2 V_{M}\left(A_{(0) 0}\right)^{2} G_{C K}}{\pi^{2}} \\
& \times\left[\sin \left[\{(k \mp 1)+1) \theta_{i}+\frac{2 \pi}{3}+\delta+\phi_{C K}\right]\right. \\
& \left.+\sin \left[\{(k \mp 1)-1\} \theta_{i}-\frac{2 \pi}{3}+\delta+\phi_{C K}\right]\right]
\end{aligned}
$$

ここて，解析にあたっては，高調波次数 $k$ は任意 の数としてきた。それゆえ，kが整数以外の場合て ち、この結果を通用することができる。また，同梾

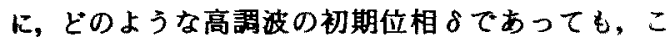
の結果を適用することができる。

\section{4. 高娚波共掁現象}

〈4・1〉离語波に奶する变换峌作 以上の検郡結 果から，入力電压に $k$ 次の高調波成分が含まれると きこれに対する值罟電流式サイクロコンバータの変 換動作を，図6のように表すことができる。

入力㑑の $k$ 次高調波電压は，正相の場合は $(k-1)$ 次に，逆相の場合は $(k+1)$ 次に，それぞれ変換され る。そして、この変的れた高調波電压によって, $G_{c r}(s)$ なる质達関数で, 循環電流系に高調波電流が 流れる。この $(k \mp 1)$ 次の偱票電流高調波は, 入力側

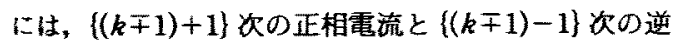
相電流とに変換される。

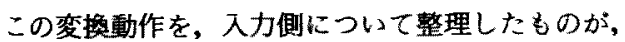
表 3 である。 $k$ 次の正相電压に対しては $k$ 次の正相電 流か，また， $k$ 次の逆相電圧に対して住 $k$ 次の逆相電 流が、入力国に現れる。それゆえ, サイクロコンバー 夕流，このk次高調波に対して流，LR 等価回路で置 き換えることができる。この等洒回路の各定数は，表 中の振楅と位相から一義的に決定される。またこの 変換動作に伴って, $(k-2)$ 次あるいは $(k+2)$ 次の高 調波垂流が発生する。

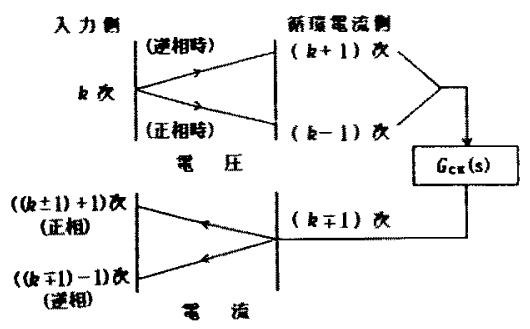

图 6 高訣波に対する変换動作 Fig. 6. The conversion process for the harmonics.
表から明らかなように、この高調波電流の振楅は， パルス数 $P$ の 2 乗に比例している。解析にあたって は, 変压器の巻数比を 1 としたので, 実除には, 高調 波電流の振愊は、サイクロコンバータ容量の 2 乗に比 例することになる（変圧器の巻数比を変え、これに庁 じてパルス数を変えても，容量が一定であれば，入力 㑡から見た等価 $L R$ 值は変わらない)。

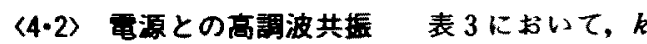
次の逆相入力電王を改めて $(k-2)$ 次と置き換えれは， このとき入力侽には， $k$ 次の正相電流と $(k-2)$ 次の逆 相電流が流れることになる。すなわち，入力電圧に $k$ 次の正相成分と $(k-2)$ 次の逆相成分とが含まれる場 合には，入力電流にも $k$ 次の正相成分と， $(k-2)$ 次 の逆相成分が含まれるようになる。

このような二つの高調波次数に対して，電源系統を 含むサイクロコンバータの等価回路を示したものが, 図7である。上述のように高䚴波電压に等しい次数と 相回䎐をもつ高調波電流は，インダタタンス值 $L_{\alpha}$ と抵抗值 $R_{c c}$ をし $2 R$ 回路で置き換えることがて きる。また，もう一方の高調波電流は，振蝠と初期位 相がこのLR 回路電流に等しい, 高謂波電流源で表

表 $3 k$ 次高調波電压印加時の入力電流高調波 Table 3. The harmonic component in the

\begin{tabular}{|c|c|c|c|c|}
\hline \multicolumn{2}{|c|}{ 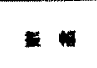 } & \multicolumn{3}{|c|}{$\frac{P^{2} 2 v_{k}(u(n))^{2} G_{1 *}}{x^{2}}$} \\
\hline \multirow{3}{*}{ 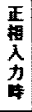 } & antite & bt & \multicolumn{2}{|c|}{$(k-2)$} \\
\hline & 拇E更 & 正 & 浇 & 青 \\
\hline & 柆 & tre & \multicolumn{2}{|c|}{$+\mathbf{n}$} \\
\hline \multirow{3}{*}{ 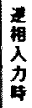 } & atale & $(k+2) *$ & \multicolumn{2}{|c|}{ 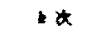 } \\
\hline & 租且它 & $\mathbb{I}$ & 柆 & 相 \\
\hline & 拉 & in. & \multicolumn{2}{|c|}{ ok. } \\
\hline
\end{tabular}
input current under input of the $k$ order harmonic voltage.

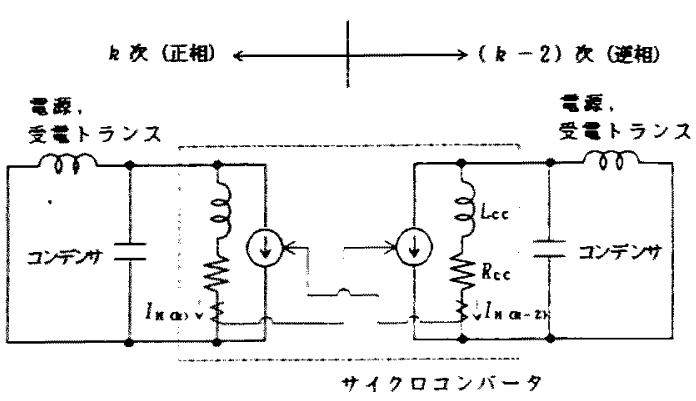

图 7 高語波共振に対する等価回路

Fig. 7. The equivalent circuit for the harmonic resonance. 
すことができる。

図 7 で示した，二つの次数にまたがる高調波共振ル ープを整理したものが図8である。ここで, サイクロ コンバータ自身が発生する特性高調波電流 ${ }^{(7)}$ や非理 論高調波電流中の, $k$ 次の正相成分を $I_{H N(k),}(k-2)$ 次の逆相成分を $I_{H N(k-2)}$ としている。そして, この外 乱成分に起因する高調波電流を, それぞれ $I_{H(k)}$, $I_{H(k-2)}$ としている。 $G_{H(K)}, G_{H(K-2)}$ は, 図 7 の電源・ 受電変圧器, 進相コンデンサならびに等価 $L R$ から 与えられる, 各次数についての電流拡大率である。

図から明らかなように，この高調波ループは正帰還 を構成しているため, 一巡伝達関数が 1 に近づく次数 では，その次数の外乱電流を大きく拡大するようにな

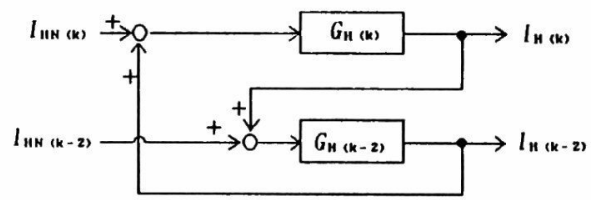

図 8 高調波共振ループ

Fig. 8. The loop of the harmonic resonance.

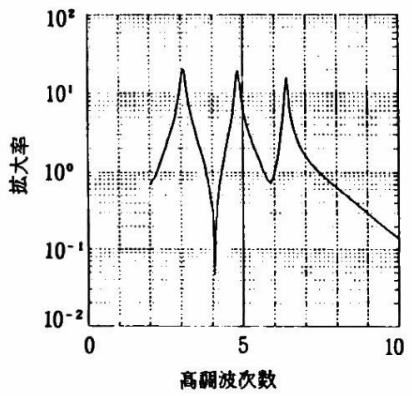

(a) $I_{H(k)} / I_{H N(k)}$

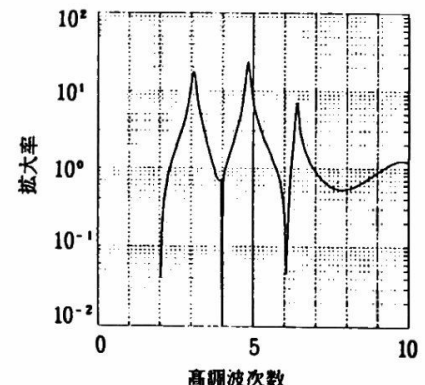

(b) $I_{H(k-2)} / I_{H N(k-2)}$

図 9 外乱電流拡大率

Fig. 9. The magnified ratio of the disturbing current.
る。また, コンデンサ容量によって,この共振周波数 は変化する。

表 2 に示す, 浮上式鉄道宮崎実験線の $16 \mathrm{MVA}$ サ イクロコンパータの各定数を用いて, この高調波共振 ループの外乱電流拡大率 $I_{H(k)} / I_{H N(k)}, I_{H(k-2)} / I_{H N(k-2)}$ を求めたものが図 9 である。ここで, 電源の短絡容量 は $320 \mathrm{MVA}$, 受電変圧器容量は $30 \mathrm{MVA}$ (\% $Z=$ $7.5 \%$ ), 進相コンデンサ容量は $48 \mathrm{MVA}$ とし, サイ クロコンパータの出力電圧比を 0.5 としている。正 相, 逆相いずれの場合においても，3 次，5次ならび に 6.5 次付近に大きな拡大率が見られる。このことか ら, 3 次と 5 次付近, あるいは 5 次と 6.5 次付近で図 8 に示す共振ループを構成し, 高調波共振現象が発生 しやすいことがわかる。

\section{5. 試験結果}

上述のサイクロコンパータを使用して, 以上の検討 結果を確認した。試験条件は, 前章の検討条件と同一 である。また, サイクロコンバータの出力電流は 0 と している。

図 10 に示すように, 高調波共振時には, 受電変圧 器（人/D結線）の二次電圧がひずみ，二次電流に高 調波成分が現れている。また，サイクロコンバータの 循環電流にも, 高調波成分が現れている。

この循環電流の高調波スペクトラムを示したもの が，図 11 である。ここでは，2 次，3 次，4.5 次な らびに 7.5 次成分が支配的である。このうち，2 次成 分と 3 次成分は, この単相サイクロコンバータ自身の 製作・調整誤差によるものである（各相のサイクロコ ンパータで,この大きさにばらつきがある)。4.5 次

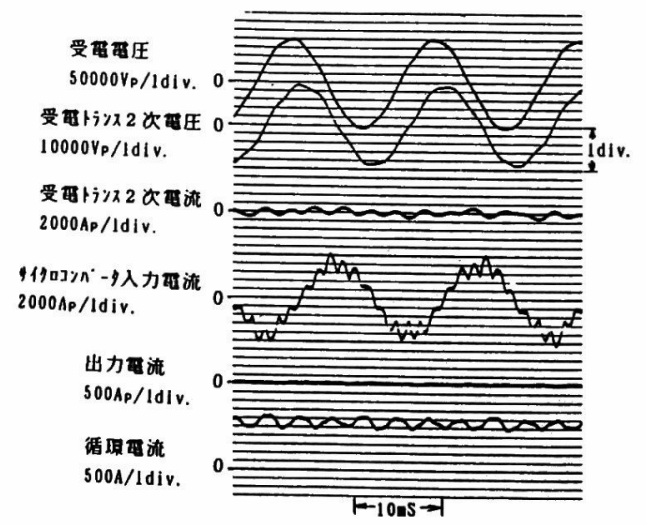

図 10 高調波共振時の各部波形

Fig. 10. The recorded waveforms in various parts under harmonic resonance. 


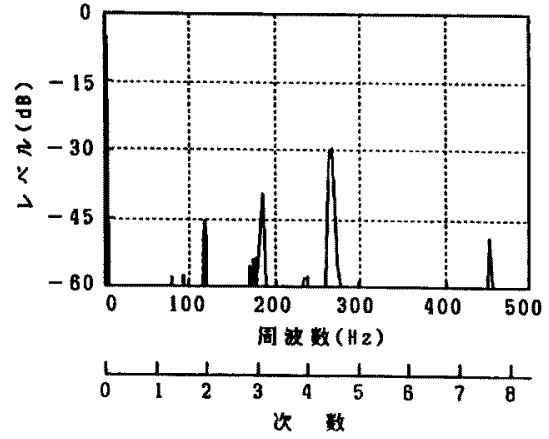

図 11 循環電流の高謂波スペクトラム（U相） Fig. 11. The spectrum of the circulating current ( $U$-phase).

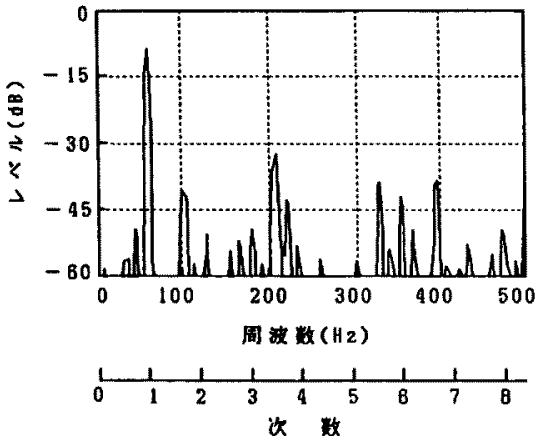

図 12 サイクロコンバータ入力電流の高調波 スペクトラム $(R$ 相 $)$

Fig. 12. The spectrum of the cycloconverter input current ( $R$-phase).

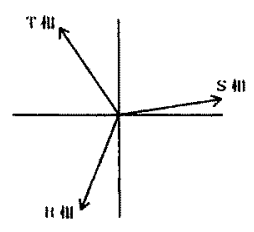

(a) 3.5 次成分

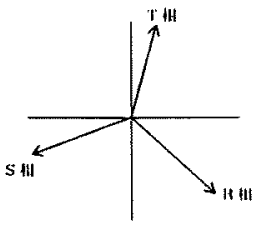

(b) 5.5 次成分

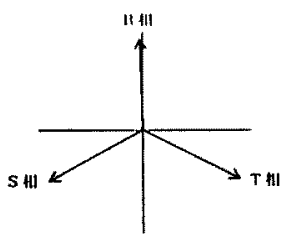

(c) 6.5 次成分

図 13 入力電流高調波成分の振幅と位相 Fig. 13. The amplitude and phase of the harmonic component in the input current.
と 7.5 次成分が，高調波共振現象によるものである。 サイクロコンバータ入力電流の高調波スペクトラム を示したものが，図 12 てある。循環電流中の 4.5 次 成分は 3.5 次と 5.5 次成分に変换され，7.5 次成分は 6.5 次（と 8.5 次）成分に変換されている。

また, 入力電流中の, 主要成分の振幅と位相を示し たものが，図 13 でる。三つの次数成分とも，良く バランスしており，3.5 次成分は逆相，5.5次成分は 正相，6.5 次成分は逆相となっている。

このように, 以上の確認試験では，前章で検討した 次数にほほ等しい 3.5 次, 5.5 次ならびに 6.5 次付近 に高調波共振現象が現れ，かつ，その相回転は検討結 果に一致するという試験結果が得られた。

\section{6. まとめ}

循環電流式サイクロコンバータでは, 電源系統〜進 相コンデンサ群〜サイクロコンバータ間て, 高調波共 振現象が発生する場合がある。本論文では，このよう な高調波共振現象について解析を行ってきた。ここ で，以上述べた事柄を要約すれば，次のようになる。

（1）循環電流式サイクロコンバータでは， $k$ 次の 入力電珐高調波に対しては, $k$ 次の入力電流高調波が 現れる。この高調波電流の相回転は, 高調波電圧の相 回転に等しい。また，更に正相電圧の場合には（ $k$ -2) 次の逆相電流が, 逆相電流の場合には $(k+2)$ 次の正相電流が現れる。

（2）これらの高調波電流の振幅は，サイタロコン パー夕容量の 2 乗に比例する。サイクロコンパー夕容 量が一定であれば，そのパルス数にはよらない（すな わち，パルス依存の高調波電流とは異なり，パルス数 を多くしても，これを低滅することはできない)。

（3）電源系統, 進相コンデンサなびにサイクロ コンパータ間の，高調波共振現象に対する等価回路を 求めた。そして, この等価回路より, 正相 $k$ 次一逆 相 $(k-2)$ 次の間で, 正帰還ループを構成すること を示し，この高調波ループの一巡伝達関数が1に近づ く次数では, 高調波共振現象が発生するようになるこ とを明らかにした。

（4）以上の検討結果を，浮上式鉄道宮崎実験線の 大容量サイクロコンバータを用いて確認した。

(平成 2 年 12 月 27 日受付, 同 3 年 6 月 11 日再受付)

$$
\text { 文献 }
$$

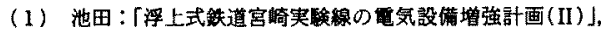
気鉃道, 38(昭 59-11)

(2) H. Ikeda, et al.: "Power Conversion System for Maglev Vehicle MLU002", 1. C. Maglev '88(1988) 
（3）彭, 他:「直列形アクティフフフィルタとLCフィルタの併用 システム」, 電学論 D, 111, (平 3-2)

(4) B. R. Pelly (西條訳) : サイクロコンバー夕(昭 51) 電気書院

（5）西條，他：「循環電流制御によるサイクロコンバー夕の無効 㫣力制御」, 電気学会研資, SPC-80-18(昭 55)

（6）多田幔, 他：「非干涉制御理論を適用した循環電流制御法の 検即」, 電学論 B, 104, 77 (昭 59-2)

（7）池田, 他:「非対称制御サイクロコンバータの入力無効電力 と特性高調波電流了, 電学論 D, 110, 14 (平 2-1)

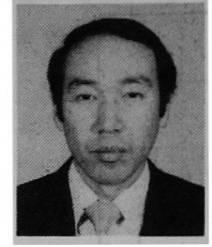

川口青夫（正員）

昭和 26 年 1 月 21 日生。 48 年 3 月明治大学工学部電気工学科卒業。 同年 4 月日本国有鉄道入社。以後, 宮崎浮上式鉄道実験センター, 鉄道 技術研究所にて浮上式鉄道の研究開発に従事。現在, 鉄道総合技術研究所にて浮上式鉄道の電力供給システ ムに関する研究開発に従事。

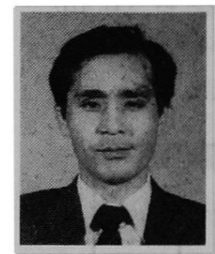

\section{加賀 重 夫 (正員)}

昭和 24 年 12 月 15 日生。 49 年 3 月中央鉄道学園大学課程電気科卒 業。以後, 鉄道技術研究所にて浮上 式鉄道の研究開発に従事。現在，鉄 道総合技術研究所にて浮上式鉄道の電力供給システム に関する研究開発に従事。 